Article

\title{
The Interdependences between Sustainability and Their Lifestyle That Pre-Service Teachers Establish When Addressing Socio-Ecological Problems
}

\author{
Patricia Esteve-Guirao ${ }^{D}$, Mercedes Jaén García and Isabel Banos-González *D \\ Departamento Didáctica de las Ciencias Experimentales, University of Murcia, 30100 Murcia, Spain; \\ p.esteve@um.es (P.E.-G.); mjaen@um.es (M.J.G.) \\ * Correspondence: ibbg1@um.es
}

Received: 21 August 2019; Accepted: 15 October 2019; Published: 17 October 2019

\begin{abstract}
In the training of pre-service teachers, promoting changes in everyday activities to favour environmental conservation is still a challenge. This paper discusses the main difficulties of pre-service teachers in the process of building relationships between sustainability and their lifestyle. For this purpose, a problem-based learning programme was designed, consisting of three socio-ecological problems. In each of them, we analysed three components which define these interdependences: pressures, importance and solutions for conservation. There were 72 participants in the whole programme and 1296 responses were assessed, by establishing three levels of sophistication for the relationships between sustainability and their lifestyle in each component. The pre-service teachers readily admitted the pressures on the environment exerted by certain everyday activities. In addition, they progressed on the identification of the importance of ecosystem services in their lives, and they pay attention to those services linked to socio-economic and cultural activities. The greatest difficulties lay in proposing solutions of conservation that involve changes in personal habits towards more-sustainable ones. These difficulties are discussed, as well as the educational implications that may be derived.
\end{abstract}

Keywords: education for sustainable development; pre-service teacher education; socio-ecological problems

\section{Introduction}

Education for sustainable development (ESD) is widely included in school curricula around the world [1] and, therefore, it should be considered an essential feature of pre-service teacher education programmes [2]. Because of its potential multiplying effect, teacher education has a key function in fostering ESD [3]. Moreover, the ideas, values and practices of pre-service teachers are important in order to adequately address ESD in schools [4-6].

In the training of pre-service teachers, one of the main goals should be to make students aware of the complex interdependences among the different sectors-ecological, economic and social—involved in sustainability. Likewise, students should be conscious of the relationships between local, everyday activities and global sustainability, as well as between the present and future generations [7]. For [5], the main approach should involve action competence, critical thinking, deliberation and an understanding of how one's choices affect the entire socio-ecological systems (SES). This approach seems essential to decrease the threats that sustainability is facing because of human activity.

Nevertheless, different authors recognise as insufficient the support for this approach from public institutions [8,9]. Despite all the plans and policies in recent decades, some goals set for schools and higher education have not yet been reached [2,10]. According to [11] (p. 2), if teachers have not had an 
'opportunity to think, practise and develop their own understanding of sustainability during their education, they are not expected to do so in their future teaching either'.

In order to prevent this form of inaction when teaching about the causes and consequences of our actions, ref. [12] underlined the importance of teachers' knowledge and behaviour. In this regard, she argued that, to involve pre-service teachers, they need to have the opportunity to reflect on their own attitudes and actions regarding socio-ecological problems. This awareness and motivation of pre-service teachers in relation to these issues is considered crucial to their involvement in the adoption of solutions as citizens, as well as to their addressing of these issues in an adequate way with their future pupils $[5,13,14]$.

Regarding pre-service teacher training, this might imply a lack of motivation to work toward real solutions to improve sustainability [15]. Therefore, in the field of teacher training, we must try to address these challenges through the development and assessment of specific educational programmes focused on issues such as biodiversity (BD) loss $[16,17]$. These programmes might encourage pre-service teachers to explore the importance of environmental conservation and to assume responsibilities with regard to this problem, so that they build clear relationships between their daily activities and sustainability. The identification and assessment of the difficulties that pre-service teachers face when they build these relationships may help these teachers' trainers to define the appropriate didactic strategies, so that they become involved in conservation tasks as citizens and as future teachers.

\subsection{The Close Relationship between Our Lifestyle and Sustainability}

In order to achieve sustainability, one must generate positive attitudes and behaviours towards the environment [18]. To reach this aim, teaching strategies should make the interdependencies between nature and humanity recognisable, with clear messages about the need for the conservation of SES and the risks involved in its threats [19]. In this sense, BD is configured as an adequate construct in the context of EDS, precisely because it reflects particularly well the interdependencies among the ecological, social and economic dimensions [20-22].

Nonetheless, the public's understanding of the importance of BD conservation seems to have declined significantly during the past decades [3,9]. In this sense, Hofman-Bergholm [12] (p. 7) suggested that a 'kind of ecological illiteracy has developed' among the population and, even, among university graduates. This implies that knowledge of some key cognitive skills for the analysis of environmental problems and skills in the use of environmental action strategies may yet be limited $[15,23]$. So, it seems that the population needs to improve its competencies to face global socio-ecological challenges [24].

Several authors have pointed out the lack of awareness about the connections between individual decisions and behaviours and certain socio-ecological problems, such as BD loss [3,21,25]. For their part, Yli-Panula et al. [18] found that many Nordic student teachers did not understand that the actions of human beings lead to BD loss. Regarding this problem, the assessment of the initial ideas of Spanish pre-service teachers also revealed a lack of knowledge about the causes and consequences of the problem [25]. Thus, it is still a challenge for the society and pre-service teachers, in particular, to build strong relationships between sustainability and our lifestyle. In this sense, Forbes and Zint [26] considered teachers' beliefs and perceived competencies to be essential determinants of teachers' practices in the context of EDS, therefore underlining 'the important role of formal teachers training in strengthening pre-service teachers' beliefs' regarding the impartment of EDS (p. 40).

Promotion of the awareness of this relationship requires a change in the human thinking regarding action, and this would be possible only by the means of critical thinking about the causes, consequences, responsibility and utility of individual actions [21]. In their study of society's awareness of the environmental impact of our daily actions, MacDiarmid et al. [27] highlighted three patterns: the tendency to minimise the role of personal habits in the global context of socio-ecological problems; a widespread lack of knowledge about the effects of our consumption on these problems; and the resistance to the modification of socially established consumption habits. In this sense, these could 
be considered as key aspects when we design teaching strategies to address the sustainability of SES. Focusing on these strategies, we define three components to promote the understanding of these relationships between sustainability and our lifestyle: (i) The pressures exerted by daily activities on socio-ecological systems; (ii) the importance of these systems in everyday situations; (iii) the conservation of SES based on daily decisions (Figure 1).

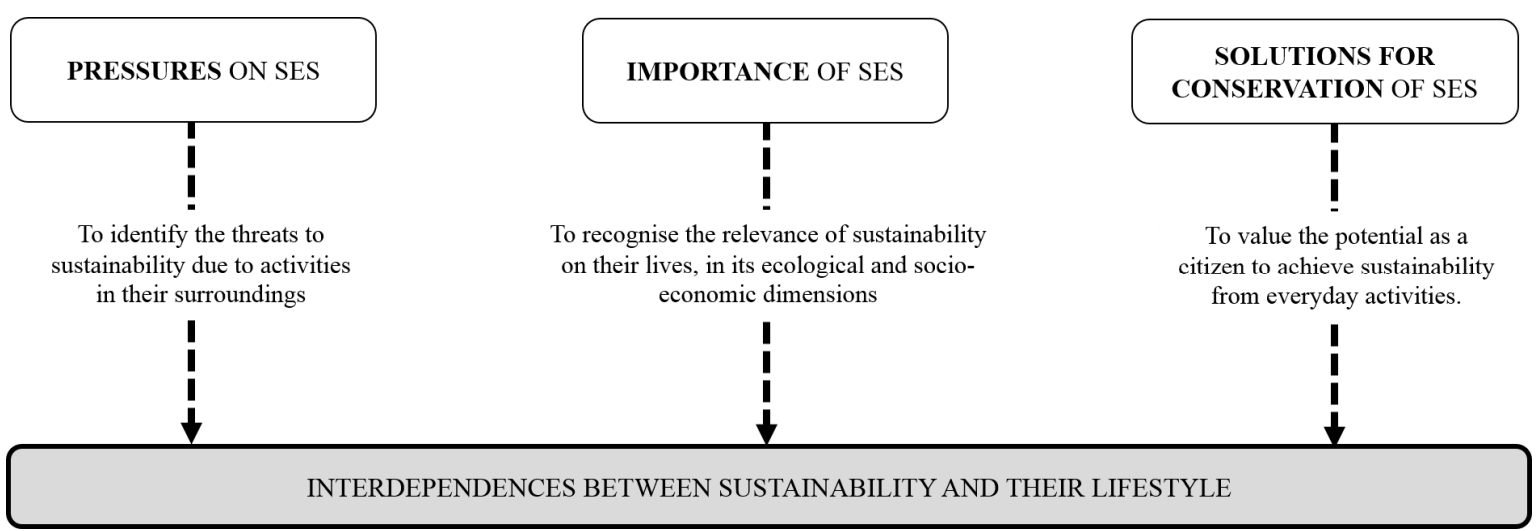

Figure 1. Key components that define the relationship between sustainability and our lifestyle, adapted from [27].

\subsubsection{Pressures on Socio-Ecological Systems Because of Certain Activities in Our Surroundings}

When the main causes of threats to nature are assessed, citizens tend to refer to industry or general pollution, as well as determined catastrophic events, such as oil spills [28]. These ideas are also widespread among young students and pre-service teachers. Often, they are unclear about the role of humans in global problems and seem unaware of which of their specific daily actions could potentially affect the environment, for example, by leading to BD loss $[21,29,30]$. Therefore, the understanding of the complex interactions among ecological and socio-economic factors which lead to socio-ecological problems seems a challenging task [18,31].

Moreover, it seems to be very difficult for them to recognise the pressures of human activities related to the agricultural sector $[32,33]$. In the area where this study was carried out (SE Spain), one of the most relevant economic activities is the development of intensive agriculture, which has entailed a strong environmental decline in the area [34]. The replacement of traditional agroforestry systems by large areas of monoculture with greater demands for chemical products, such as fertilisers and pesticides, has generated impacts, for instance, related to the eutrophication of waters. This is the case of the Mar Menor, a costal lagoon in this region, in which the entrance of agricultural nutrients has triggered changes in the environment, such as the massive presence of jellyfish.

Students' perceptions of global socio-ecological problems and the generalised lack of understanding about these pressures should be taken into account in educational approaches, to bring them into conflict in order to achieve the recognition of the unsustainability of the food production and distribution system [33].

In the current context, these production and consumption practices are of great relevance to sustainability, within its ecological, economic and social dimensions. The artificial creation of continuous needs in our society and the disconnection between the places of production and consumption have increased the overexploitation of resources [35]. In turn, this form of consumerism implies the inefficiency and inequity of the food system, as well as the massive production of waste and its entry into natural systems. For example, the growing pollution of the seas and oceans by plastics has become a problem of planetary magnitude [36]. An economic, social and environmental equilibrium is difficult with the current parameters of exploitation and consumption [29]. In this sense, Nisiforou and Charalambides [9] suggested that awareness of these problems should be focused on the links between production and consumption, individual habits and the conservation of SES. Therefore, it is 
necessary to deepen our knowledge of the pressures exerted by our lifestyle and explore how different educational instruction could improve the understanding of how daily activities are essential to the achievement of sustainability [37-40].

\subsubsection{Importance of Socio-Ecological Systems in Our Everyday Lives}

The interdependencies between nature and society tend to go unnoticed, which is one of the reasons why people do not recognise the urgency of acting in the face of the environmental crisis, as demanded by the scientific community $[8,40]$.

In order to recognise our dependence on the good state of environmental conservation, different types of projects have been developed, including the Millennium Ecosystem Assessment [41]. This project defined and differentiated four types of ecosystem services: provisioning, cultural, regulating and supporting. The provisioning services are recognised easily by the general population, especially when referring to a direct source of food or medicinal products [42]. The cultural services, such as shellfishing or silk production, are considered non-material benefits and are not so evident. The regulating and supporting services are also not so apparent because of the high degree of complexity of the processes that they sustain, such as pollination or material recycling.

In the building of relationships between sustainability and daily activities, cultural, regulatory and supporting services, linked to the socio-economic and cultural framework, seem especially interesting, since they are distanced from the idea of nature as a resource [43]. For [44], the recognition of these services reduces the risk of producing excessively utilitarian reasoning; in this sense, Kellert [45] highlighted the unsustainability of a socio-economic development model alien to the ecological system in which it is integrated. Comprehension of the complex interdependencies between nature and society is an essential condition for understanding the urgent need for an improvement in environmental quality through our daily actions [18].

In the educational arena, addressing the importance of SES from the perspective of ecosystem services could help to build these interdependences [41,45]. In the case of BD loss, almost half of the European citizens, when surveyed, did not think that they would be personally affected by this problem, despite the effects on the balance of ecosystems and on the current and future human well-being, in terms of human health, the economy and social relationships [46-48].

It has been shown that the perception of the need to conserve the environment increases when students appreciate the important implications of its threats for their family or personal surroundings [49]. Therefore, it seems that the educational strategies with this aim could favour an interpretation of global socio-ecological processes in local and significant contexts by students. This would capture their interest and have great potential to generate useful knowledge that is transferable to their daily lives [50].

\subsubsection{Conservation of Socio-Ecological Systems Based on Our Everyday Activities}

One of the main controversies in EDS relates to the gap in the students' knowledge, together with their attitudes and behaviours [51]. These authors highlighted the complexity of explaining pro-environmental behaviour, since it is not possible to explain the direct relationship between knowledge and behaviour or between attitudes and behaviour in a reductionist way [52]. In fact, pro-environmental behaviour, understood as 'any action that enhances the quality of the environment, regardless of intent' [53] (p. 2), is determined by a number of interacting factors which have been grouped as internal and external factors [52].

Among the external factors are found norms, traditions and sociocultural factors, transmitted by the social environment. Zsóka et al. [54] highlighted the effects of the latter for university and high school students, along with stimuli arising from the immediate environment-including family, friends, neighbours and education.

The internal factors include knowledge, attitudes, emotions and individual values [53]. Otto and Pensini [55] stated that environmental knowledge is a prerequisite for pro-environmental behaviour, 
although the relationship between them has been disputed. According to numerous authors, knowledge of natural phenomena and humans' impact on the environment is not enough to be able to act sustainably $[52,56]$. The findings of [9] showed that undergraduate students were unwilling to change their daily behaviour, despite possessing a fair knowledge of biodiversity and positive attitudes towards its conservation. Attitudes are defined as 'enduring positive or negative feeling about some person, object or issue' [51] (p. 252). Regarding emotions, Büssing et al. [22] recognised them as additional predictors of behavioural intentions and, therefore, they also play a pivotal role in decision-making about consumption. Whereas, individual values, understood as abstract ideas, such as sustainability and equality [52], could contribute to our decision-making capabilities, framing our attitudes and leading us to engage in associated behaviours.

In order to establish a more holistic approach towards this controversy, Olsson et al. [57] proposed the introduction of the concept of sustainability consciousness as 'a concept that integrates the environmental, social and economic dimensions of sustainable development' (p. 183). For these authors, this concept may reflect students' action competence for critical thinking and democratic citizenship for a sustainable future.

This action competence should deal with the generalised lack of responsibility and lead the changes needed to face socio-ecological problems $[13,58]$. In order to redefine students' behavioural patterns, an emancipatory educational approach, oriented to explore and challenge collective and personal values, attitudes and behaviours, may contribute to global sustainability $[18,59]$. The attention must focus on the possibilities of active participation and on reinforcing the faith in the power of change, generating expectations for actions, which should be real, effective and close to their everyday lives [29].

In this sense, the analysis and reflection about the sustainability of our forms of consumption are particularly interesting $[25,60]$. Especially, pre-service teachers usually find it difficult to establish adequate relationships between their consumption habits and problems such as the BD loss, which can condition them to make concrete and realistic commitments [61]. The results of different educational interventions aimed at promoting sustainability in teacher training seem to have favoured the establishment of these relationships, and the pre-service teachers showed greater willingness to change their consumption patterns [25]. The importance of this willingness lies in the fact that teachers who feel a personal responsibility to solve socio-ecological problems are those who, more often, involve pupils in activities related to the care of the local environment and encourage them to take on commitments [62]. In fact, for [63], 'teachers' (and pre-service teachers') pedagogical and environmental beliefs are more important in guiding their teaching about controversial socio-ecological issues than have previously been recognised' (p. 69). Then, if we accept that what teachers know and believe directly affects classroom content regarding EDS [64], and because of the lack of insights into these issues [63,65], more research is needed to go further into the difficulties that pre-service teachers find when they build the relationship between sustainability and their lifestyle.

\section{Aims of This Work}

The importance of pre-service teachers' beliefs regarding sustainability, addressed as part of the theoretical background, allows us to establish the aim of this work. Thus, we aim to identify and discuss the main difficulties faced by pre-service teachers when they build these relationships between sustainability and their lifestyle during an educational intervention. We analyse the progression of the defined key components, in order to identify the most important barriers when our students try to:

- Identify the pressures on SES because of certain activities in their surroundings.

- Recognise the importance of SES in their everyday lives.

- Propose solutions for conservation of SES based on their everyday activities. 


\section{Methodology}

\subsection{Participants}

The research was implemented with 72 students of the Degree of Primary Education (University of Murcia, Spain). The students' mean age was 21.7 years $(\mathrm{SD}=0.66)$ and the female gender was dominant within the sample $(76.39 \%)$. All the participants were studying the compulsory subject 'Teaching and Learning about the Natural Environment'.

The participating pre-service teachers were grouped into 20 small work teams, which were kept stable during the whole intervention. Previously, the participants had been informed about this research and all of them gave their approval.

\subsection{Intervention Programme}

For the design of the intervention programme, the problem-based learning approach was identified as a valuable didactic strategy, since it allows students to explore real situations-in this case, related to sustainability $[49,60,65]$.

In the selection of the contents, attention was paid to the students being able to contrast their ideas about how closely linked daily activities are to the achievement of sustainability. Significant contexts were selected, in which the students could feel involved and develop the ability to analyse, negotiate and discuss the problems raised, for critical decision-making, so that the acquired knowledge could be transferred to their everyday lives [66].

This proposal was composed of three socio-ecological problems [67], by placing special emphasis on the interdependences of ecological, social and economic dimensions by means of ecosystem services (Table 1). The selected problems allowed us to address socio-ecological problems at different scales (from global to local), as well as the role of the students in these problems (from the collective to the individual level). The intervention programme was structured into eight lessons, developed along four weeks.

Table 1. Description of the problems that make up the didactic intervention.

\begin{tabular}{|c|c|c|}
\hline Problem & Approach & Contents \\
\hline $\begin{array}{l}\text { Problem: 'Why are there so many } \\
\text { jellyfish in the Mar Menor coastal } \\
\text { lagoon?' }\end{array}$ & $\begin{array}{l}\text { They start from a residents' } \\
\text { meeting being called in a coastal } \\
\text { town of their region, to discuss } \\
\text { neighbourhood actions regarding } \\
\text { the eutrophication of the coastal } \\
\text { lagoon. }\end{array}$ & $\begin{array}{l}\text { Analysis of the problem of eutrophication of a } \\
\text { regional coastal lagoon and of the conflicts between } \\
\text { two relevant sectors of the regional economy: } \\
\text { agriculture and tourism. } \\
\text { Assessment of the importance of the biodiversity to } \\
\text { minimise the consequences of the eutrophication. } \\
\text { Identification of the feasibility of different solutions } \\
\text { for this problem. }\end{array}$ \\
\hline
\end{tabular}

Based on the proposals of $[65,68]$, the development of our educational intervention was structured into two main stages:

1. Identification of the problems. Here, each problem was raised and the students explored and explained their related ideas and values. In the first problem, the pre-service teachers considered the effect of the fishery trade, as well as the responsibility and potential solutions. In the second 
problem, about eutrophication, they valued the consequences of the massive presence of jellyfish and the effects of their eradication. In the last problem, the pre-service teachers offered several explanations about the existence of the garbage vortex, the origin of the plastic wastes, as well as feasible strategies to reduce marine pollution by plastics.

2. Solving of the problems. Working in collaborative groups, the pre-service teachers performed different open-ended activities to achieve their own inquiry process through descriptive and extrapolation tasks $[69,70]$. During this process, different resources were addressed, such as real data, scientifically relevant reports or news bulletins, opinions of scientists and social agents, among others. In the first problem, all these resources concerned the impacts of our diet, the consumption pattern of Spanish citizens and the production and distribution model of the food we usually consume. In the second problem, the agricultural and touristic development of the surroundings of the costal lagoon in the last decades and the socio-ecological consequences were addressed. In the third problem, these resources concerned the effects of the marine wastes and the assessment of their own consumption of these products.

\subsection{Data Collection}

In each problem, the pre-service teachers prepared a personal report with two major sections: 'identification of the problem' and 'final conclusions'. By means of the 72 collected reports, the progression in their ideas could be assessed.

In the first section, the students' responses revealed their initial ideas about the pressures generated by the studied problems, the importance of their consequences as well as the most adequate conservation strategies. This way, the initial abilities of the pre-service teachers to relate each of these aspects to everyday activities could be assessed. In the second stage, which was written after the inquiry process, the pre-service teachers reviewed their initial ideas and they elaborated new conclusions. In this way, 1296 responses were collected, 432 for each component.

\subsection{Data Treatment}

To assess and compare the overall progression of their personal construction regarding some socio-ecological problems and their lifestyle, the written responses were read to identify fragments of meaning of each key component of these constructions: 'Pressures', related to the causes of the problem identified by the pre-service teachers; 'importance' of the interdependences between nature-society that they established; and 'conservation', related to the role that they give to the citizens and themselves to achieve sustainability.

In the next step, the sophistication of the relationships between sustainability and our lifestyle, for each component, was assessed. This allowed us to establish three levels for each component, whose description is shown in Table 2:

i) 'Pressures': In this component, the complexity of ideas was distinguished, in line with [39]. These ideas may be irrelevant or non-normative, when they include invalid explanations about pressures; partial ideas, when they identify pressures, but their explanations are poorly elaborated; or accurate ideas, when they specify the pressures, and even link several valid explanations [39].

ii) 'Importance': In this component, their answers were assessed based on the kind of relationships established between ecological and socio-economic aspects, according to [43]. These connections could be not-apparent, when they relate the ecosystem services only to natural aspects; linear connections, when they recognise provision services; or non-linear connections, when they accept that some socio-economic activities depend on ecosystem services.

iii) 'Conservation': In this component, the pre-service teachers considered the own potential as agents to solve problems through changes in their daily activities, in line with the routes of change proposed by [59]. Therefore, the suggested solutions can be considered a passive change, when it is not about citizens' own choices, but through institutional measures; poorly specific changes, 
when solutions are based on what citizens should do, although this is not specified, in their everyday lives; or personal active changes, when they make statements about their own habits.

Table 2. Description of the levels of the relationships between sustainability and lifestyle, for each component.

\begin{tabular}{clll}
\hline Levels Components & \multicolumn{1}{c}{$\mathbf{1}$} & \multicolumn{1}{c}{$\mathbf{2}$} & \multicolumn{1}{c}{3} \\
\hline Pressures & $\begin{array}{l}\text { They identify pressures } \\
\text { because of the activities } \\
\text { in their surroundings } \\
\text { through non-normative } \\
\text { ideas. }\end{array}$ & $\begin{array}{l}\text { They identify pressures } \\
\text { because of the activities } \\
\text { in their surroundings } \\
\text { through partial ideas. }\end{array}$ & $\begin{array}{l}\text { They identify pressures } \\
\text { because of the activities } \\
\text { in their surroundings } \\
\text { through accurate ideas. }\end{array}$ \\
\hline Importance & $\begin{array}{l}\text { They recognise the } \\
\text { importance of ecosystem } \\
\text { services only for nature. }\end{array}$ & $\begin{array}{l}\text { They recognise the } \\
\text { importance of ecosystem } \\
\text { services for nature and } \\
\text { direct provision of } \\
\text { certain products. }\end{array}$ & $\begin{array}{l}\text { They recognise the } \\
\text { importance of ecosystem } \\
\text { services for nature and } \\
\text { socio-economic and } \\
\text { cultural activities. }\end{array}$ \\
\hline Conservation & $\begin{array}{l}\text { They propose solutions } \\
\text { for conservation, which } \\
\text { imply passive changes in } \\
\text { their everyday activities. }\end{array}$ & $\begin{array}{l}\text { They propose solutions } \\
\text { for conservation, which } \\
\text { imply little specific } \\
\text { changes in their } \\
\text { everyday activities. }\end{array}$ & $\begin{array}{l}\text { They propose solutions } \\
\text { for conservation, which } \\
\text { imply personal active } \\
\text { changes in their } \\
\text { everyday activities. }\end{array}$ \\
\hline
\end{tabular}

In this process of analysis, two independent researchers were involved to ensure the confidence and reliability [71]. The discrepancies were discussed to reach an agreement and an acceptable inter-rater reliability coefficient of 0.80 was calculated.

For the inferential statistical treatment, each response was assigned a value of 1,2 or 3 , depending on the level of relationship determined. Then, a global mean value was calculated for both time-points (identifying and solving the problems), for each component and for each problem.

For the comparison of the components, the Kruskal Wallis H statistic was applied and a post hoc analysis was carried out using the W Mann Whitney test. For the analysis of the progression of each component, the non-parametric W Wilcoxon statistic was applied. Both tests had a significance level of $\alpha=0.05$.

\section{Results}

In this section, the progression of the students' answers for the components ('Pressures', 'Importance' and 'Conservation') is analysed, including representative examples of them. Then, the statistical differences in the progression for each component and each problem are compared.

\subsection{Pressures on Socio-Ecological Systems Because of Certain Activities in the Immediate Surroundings}

In the stage of identification of problems, all students admitted the unsustainability of some human activities developed in their surroundings or related to their forms of consumption, but their arguments tended to be partial (2-level). For instance, when assessing whether food consumption can affect SES, most of the answers were general, such as 'The consumption of some foods can affect biodiversity, for example, a species because the place it inhabits is damaged' [Student 19]. Both in the second and in the third problem, there were references to discharges, without specifying the human activities that produce them: 'Lots of polluted water are dumped into Mar Menor lagoon' [Student 41]; or 'Many plastics are poured into oceans, where they are affecting marine life and reaching everywhere' [Student 2].

Only a quarter of the responses included arguments with a higher level of accuracy (3-level). Basically, the students recognised the overexploitation caused by the different human activities. In the first problem, the pre-service teachers pointed out some pressures that our country (Spain) exerts over the resources of non-developed countries. In the second problem, they connected eutrophication and 
the intensification of some activities, such as agriculture. In the last problem, they offered explanations which related overfishing to plastic wastes: 'There is tremendous damage caused by the fleet of fishing boats, which also cause the death of thousands of fish, overfishing and the remains of nets and other garbage left in the sea. Little is known about this when one is going to make the purchase' [Student 39].

In the stage of solving of the problems, less than $10 \%$ of the responses remained at 2-level; the rest of the students seemed able to build a higher level of relationship (3-level). For example, regarding the consumption of food, all students related the high demand for meat to the production of methane that intensive livestock farming involves, and almost half of them referred to the low energy efficiency of meat production compared to vegetable production, relating it to the loss of natural resources: 'I eat too much meat without knowing that to obtain the same protein or energy as with vegetables, more crops, more pesticides and more water are needed' [Student 13]. In the case of the Mar Menor lagoon, almost the totality of the students appropriately identified the entry of nutrients from agricultural activity, but they also pointed out other pressures, such as those related to tourism and engineering works. Regarding marine pollution, they emphasised the mass consumption of plastic products and they specified how their own waste could end up in the sea.

\subsection{The Importance of Socio-Ecological Systems in Everyday Situations}

In the stage of identification of the problems, when students valued the importance of SES, basically, they offered responses focused on the natural environment, classified as 1-level. In the first problem, they referred to negative impacts on the ecosystem, above all, because of the disappearance of species and the derived imbalance in the trophic chains. In the second problem, many of these students emphasised again on the importance of conservation of species. Nevertheless, when analysing the possibility of eradication of jellyfish, they took a stance in favour, without assessing the possible effects on the ecosystem. This indicates possible contradictions when assessing the disappearance of species, depending on the context in which it occurs. Regarding the marine pollution, the third problem, their answers also were focused on ecological aspects: 'If the seas are polluted, some marine beings will not be able to survive and could become extinct' [Student 28].

On the other hand, one-third of the respondents considered simple interdependences (2-level), since, in addition to ecological aspects, they also referred to the loss of certain foodstuffs, in all the addressed problems. For example, they related water pollution to a decrease in commercial species.

Only slightly more than $5 \%$ of the responses were 3-level, where the relationships of ecosystem services and socio-economic activities were specified. In the first problem, they mainly mentioned the loss of fishing culture in the area where the Nile perch is caught. Whereas, in the second and third problems, the emphasis was placed on socio-economic activities linked to the sea; albeit, their answers were more detailed regarding the regional problem (the second one).

In the stage of solving the problems, except for three students who remained at the 1-level for the three problems, the rest achieved higher relationship levels. Almost all the responses recognised the importance of the ecosystem services for the natural environment and society, as a food resource (2-level). For instance, they mentioned: 'Eating seafood and fish depends on the species and marine ecosystems conservation' [Student 3].

Furthermore, over $75 \%$ of the responses pointed out the interdependence of environmental conservation and socio-economic and cultural development (3-level). In the first problem, they recognised that the introduction of the Nile perch meant an impoverishment of the local population, with less access to food, the appearance of diseases and conflicts. Regarding the second problem, the pre-service teachers connected nature to job generation and regional economic growth; but they also recognised the important role of the jellyfish, which previously they were willing to eradicate: 'Jellyfish are saving our Mar Menor lagoon and the tourist activity. There are many jobs related to tourism, which depend on the water quality of this place' [Student 64]. For the last problem, they included interesting appraisals such as the vulnerability to marine pollution of the poorest societies, because of their dependence on the environment or the lack of resources for waste disposal. 


\subsection{Conservation of Socio-Ecological Systems Based on Everyday Activities}

In the stage of identification of the problems, when the pre-service teachers were asked to look for solutions of conservation in the face of socio-ecological problems, only governments or businesses were held responsible. Within the three problems, it was indicated that governments must impose stricter rules to prohibit the sale of some products or to reduce pollution levels. Since they did not recognise their own role, this was considered a passive commitment and, therefore, over $15 \%$ of the answers remained at the 1-level.

However, in most of the answers, the students did recognise the need to act as citizens, although without proposing personal changes in their own daily activities (2-level). In the case of the food system, they pointed that: 'People should know where the food they buy comes from, in order to avoid buying products such as the Nile perch. If there is no demand, [those foods] will not be produced anymore' [Student 55]. Within the second and third problems, they suggested citizen's mobilisations in order to demand the proper disposal of waste left on the beach.

Specifically, only a few answers showed a more personal reading of the necessary solutions and indicated the changes in their habits (3-level). In the first and third problems, the pre-service teachers considered the reduction of the consumption of Nile perch or plastics, respectively: 'I realise that I generate a lot of plastics weekly and I have to reduce this, for example, using reusable water bottles' [Student 72]. About the Mar Menor lagoon, they specified the participation in conservationist actions, promoted by associations of ecologists.

Regarding the stage of solving the problems, although there were some references in need of government action on agricultural and tourism management, all responses recognised the need for changes in daily activities and proposed different ways of acting. Nonetheless, the majority of replies did imply little specific change in their everyday habits (2-level). Within the three problems, the pre-service teachers offered collective approaches rather than individual proposals. For example: 'If more organic food is consumed, farmers are helped and less chemical products, such as pesticides or fertilisers, are used and, thus, biodiversity is conserved' [Student 8]; or 'Citizens must be more responsible for our waste, do not leave them on the beaches and pick up the garbage that we find' [Student 47].

Only a third of these responses included proposals that would involve active changes in the everyday life of the students and so can be considered 3-level. These proposed more sustainable personal food consumption, above all, prioritising local and ecological products: 'When buying, I will review the labels to give priority to local products, even if this means stopping buying things that I like. This would help our region and I will also avoid buying food from conflict zones' [Student 31]. In the second problem, they suggested the importance of informing about the role of the jellyfish, to avoid summer holidaymakers removing them. In the last problem, the pre-service teachers seemed to be willing to substitute some single-use plastic products, such as the flasks of water provided by canteens, and other measures such as avoiding the use of plastics bags and the purchase of over-packaged products. Moreover, in this problem, the need to raise awareness in society was set out; in this sense, some students reflected on their role as future teachers, to address this issue at school: 'People should be aware of the dimension of the problem [of marine pollution by plastics] and, as a teacher, I think it would be interesting for my pupils to know about it and I will actively involve them in reducing the use of plastic' [Student 14].

\subsection{Comparative Analysis in the Progression of the Components and the Problems}

The global median value in each problem was calculated for each component, for both time-points (Table 3), since the data were on an ordinal scale with a very small range. There were no statistically significant differences among the problems.

Of the three problems, the lowest averages, in both stages, were found regarding the plastic vortex. It seems that the pre-service teachers found difficulties when relating their everyday life to the impacts that plastic produces in the sea. They considered its importance but, above all, from an ecological dimension; thus, in their proposals aimed at solving this problem, they did not reflect enough about their own consumption. 
Table 3. Description of the median values for each component in each problem.

\begin{tabular}{ccccccc}
\hline Components & \multicolumn{2}{c}{ PRESSURES } & \multicolumn{2}{c}{ IMPORTANCE } & \multicolumn{2}{c}{ CONSERVATION } \\
\hline Problems & Identification & Solving & Identification & Solving & Identification & Solving \\
\hline P 1 & 2.00 & 3.00 & 1.00 & 3.00 & 2.50 & 2.60 \\
P 2 & 2.00 & 3.00 & 1.00 & 2.66 & 2.00 & 2.00 \\
P 3 & 2.33 & 3.00 & 1.00 & 3.00 & 2.00 & 2.50 \\
\hline
\end{tabular}

Regarding the highest averages, these are shared between the other two problems. The second of them ('Why are there so many jellyfish in the Mar Menor coastal lagoon?') had the highest values regarding the importance that the pre-service teachers established between this singular ecosystem and their everyday lives. They discussed the importance of the jellyfish and also the interest of these natural surroundings for socio-economic activities. However, they showed difficulties, above all when suggesting adequate strategies for its conservation, since they did not focus on personal actions. Whereas, in the first problem ('Served biodiversity?'), the highest average regarding conservation solutions was found. This could have been influenced by the fact that the presentation of the problem and the inquiry activities were focused mainly on the daily food consumption; this could have helped the pre-service teachers to establish more significant relationships and, therefore, more personal statements.

Regarding the progression of the components, in the stage of identification of the problems, the three components had an average value close to 2 , so that the pre-service teachers seem to have established simple or poorly accurate relationships between sustainability and everyday activities (Figure 2). The 'Pressures' component had the highest average $(M=2.23, S E=0.05, M d n=2.20)$, only slightly higher than that of 'Conservation' $(M=2.19, S E=0.04, M d n=2.14)$. These data show that they admitted how activities in their surroundings affect the environment and the need for citizens to change some habits but, in both cases, their responses tended to be partial or non-specific. 'Importance' obtained the lowest value $(M=1.84, S E=0.04, M d n=1.75)$, because the majority of the students recognised the importance of ecosystem services only for natural environment.

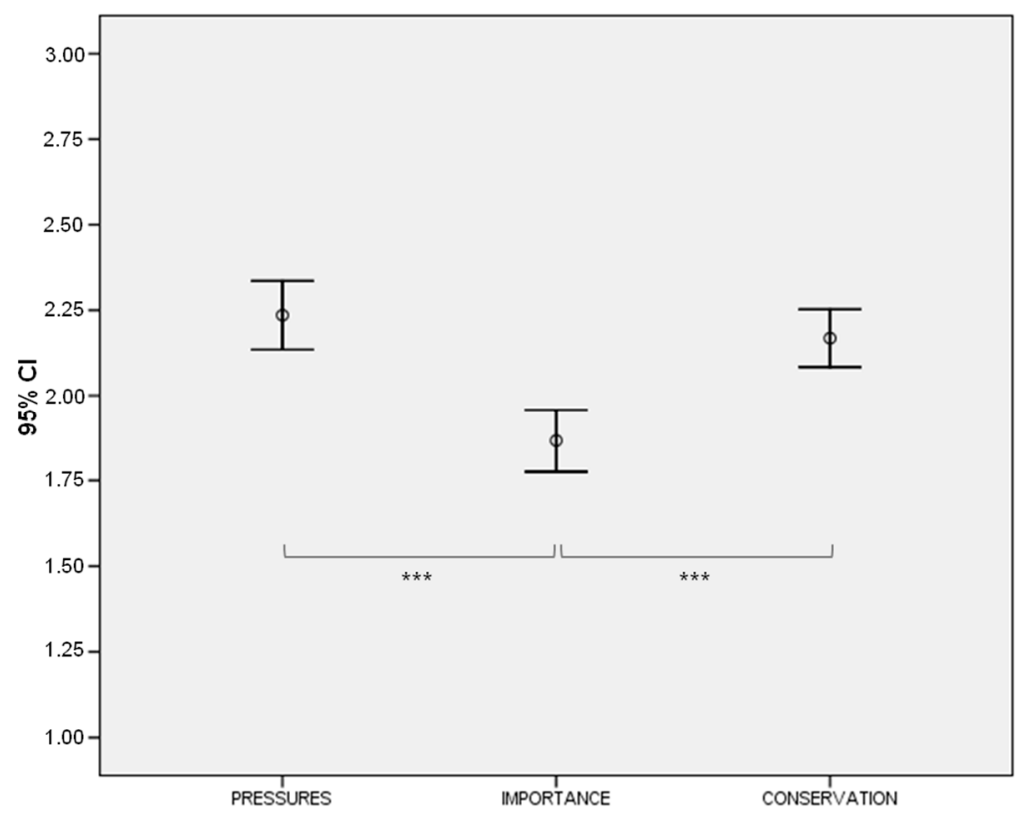

Figure 2. Error bars illustrating the distribution and differences among components in the stage of identification of the problem, where ${ }^{* * *}$ means $p<0.001$.

There were statistically significant differences among the components-in particular, between 'Importance' and the other components, 'Pressures' $(Z=-5.892, p<0.001)$ and 'Conservation' 
$(\mathrm{Z}=-5.378 ; p<0.001)$. These differences suggest some difficulties in the recognition of the socio-economic dimension of the ecosystem services.

In the stage of solving the problems, the three components had higher averages than in the identification (Figure 3). This progression of the components, in all cases, was significant: 'Pressures' $(\mathrm{Z}=-5.192, p<0.001)$; 'Importance' $(\mathrm{Z}=-6.284, p<0.001)$; and 'Conservation' $(\mathrm{Z}=-3.202 ; p=0.001)$.

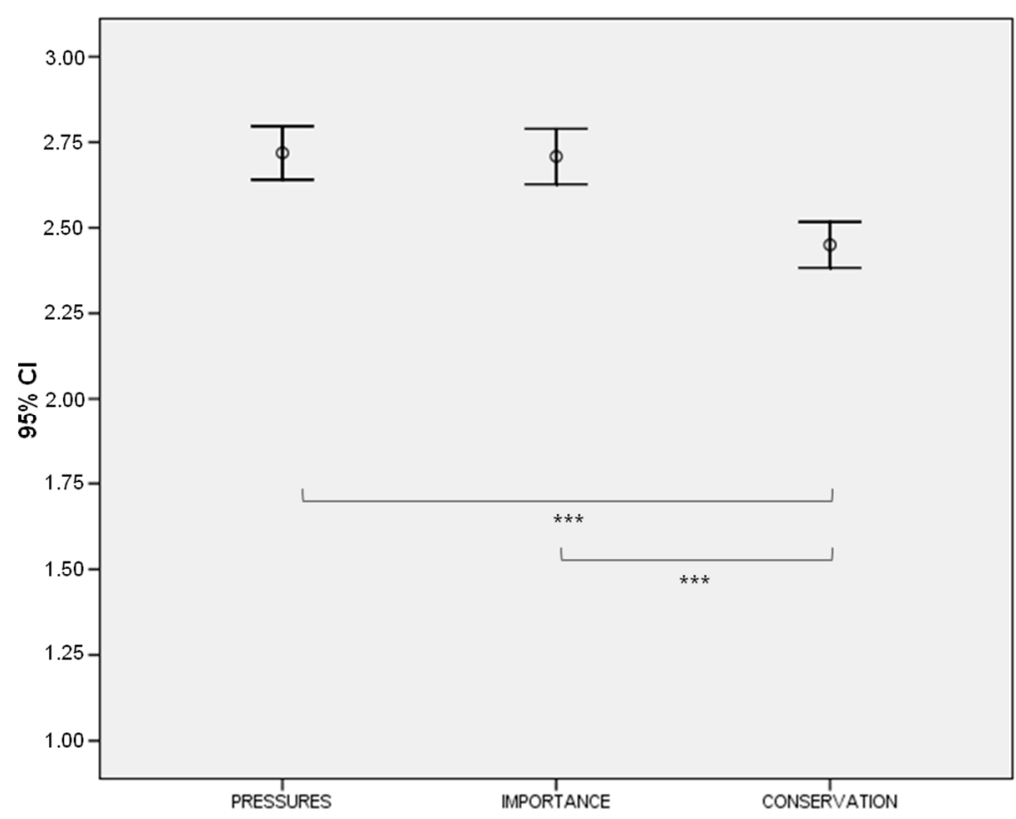

Figure 3. Error bars illustrating the distribution and differences among components in the stage of solving the problem, where ${ }^{* * *}$ means $p<0.001$.

'Pressures' was again the component with the best result $(M=2.72, S E=0.03, M d n=2.75)$, followed by 'Importance' $(M=2.70, S E=0.02, M d n=2.67)$, which experimented a greater progression. These data suggest that, in this stage, the pre-service teachers' responses were more accurate regarding the impact of their everyday activities and that they recognised socio-ecological interdependencies. 'Conservation' obtained the lowest average value $(M=2.45, S E=0.03, M d n=2.50)$, since most of the students proposed little specific individual change in their lives.

In this case, there were significant differences between both 'Pressures' and 'Importance' and 'Conservation' ( $\mathrm{Z}=-5.276, p<0.001$ and $\mathrm{Z}=-5.183, p<0.001$, respectively). Therefore, in this stage, the difficulty seemed to be the proposal of solutions linked to personal active changes in behaviour.

\section{Discussion and Educational Implications}

In the intervention programme, the problem-based learning approach was identified as a valuable didactic strategy, since it allowed the pre-service teachers to explore real socio-ecological problems and to progress in establishing relationships between sustainability and their everyday activities $[49,60,65]$. Changes in their ideas occurred in the three problems as well as in the three components considered for their analysis (pressures, importance and conservation).

In their initial ideas, the pre-service teachers addressed environmental problems from an ecological point of view, mentioning alterations in the ecosystems or pollution, which were valued as highly severe. However, they hardly specified the importance of the socio-economic dimensions, except in the case of the problem of the Mar Menor, as will be discussed later. Moreover, when they were asked to suggest conservation solutions at the beginning of the intervention, they tended to focus on the wording of the problems (such as "do not consume Nile perch"), which does not suggest active personal changes. 
Nonetheless, it can be highlighted that, by means of the open-ended activities, which included discussions of their ideas and assessment of their personal habits, the pre-service teachers progressed in the three components. Thereby, they achieved higher levels of accuracy when, again, identifying the pressures of our socio-economic model and of their own behaviours, as well as the interdependences between nature and society. Despite this, some of the pre-service teachers remained reluctant to adopt specific changes in their habits towards more sustainable ones, independent of the problem. Thus, the old behavioural patterns were a major barrier to be overcome to achieve environmental conservation [51]. This may be related to the different strategies that citizens use to avoid contradicting their consumption desires [72], as well as the tendency to dilute personal responsibilities, by holding institutions or companies responsible for the changes needed to achieve for a more sustainable consumption model [52].

Albeit three real socio-ecological problems were addressed in our programme, there were different contents in each of them, different scales of the problems (from global to local) and different level at which the pre-service teachers had to value their own actions and decisions. These differences need to be taken into account when we assess the educational intervention. In this sense, the in-depth analysis of the progression of each component offers very interesting results about the approaches to the selected problems, which allow the discussion of the education implications of our intervention.

When they addressed a regional problem, the pre-service teachers seemed to become more involved and exert themselves more in order to recognise indirect ecosystem services associated with the conservation of the Mar Menor lagoon. In this way, they were able to significantly assess its importance for socio-economic activities, above all, related to the tourist sector, possibly because it is very close to their interests. They also recognised the need to preserve poorly appreciated organisms, such as jellyfish, for which, initially, some students agreed with their eradication.

Furthermore, the students' proposals regarding this regional problem revealed some difficulties related to the socio-economic development model and these proposals did not reach the expected level, since the majority of them suggested technical solutions for the filtration of the agricultural spills. Thus, they did not discuss the problems associated with intensive agriculture; for instance, the features of the production and marketing of these agricultural products, as well as the ease of access to their consumption, issues which very relevantly underlie the generation of this problem.

Despite their interest in conserving the lagoon and its importance for regional development, the pre-service teachers' solutions were those of an indeterminate social collective. It seems easier for them to take responsibility within a collective activity, rather than at the personal commitment level [73]. The evident connection between the intensive agriculture of the area and the eutrophication of the lagoon [34], which was analysed during the didactic intervention, clearly impacts the economic situation of the affected companies. Sometimes, this led the pre-service teachers to take incoherent stances in which they even defended contradictory positions [74].

This generalised progression of pre-service teachers' perceptions about their role in the sustainability of the SES coincides with the results of other research, focused on the effect of the problem-based learning approach aimed at improving values, beliefs and pro-environmental behaviour $[65,68,75]$.

The importance of these findings, according to [26,76], lies in the fact that the improvement in the pre-service teachers' beliefs could be related to the development of certain competencies regarding the selection of effective didactic proposals for EDS in the primary school [49], as has been shown in [67]. In this sense, initial teacher training programmes should offer opportunities for the reflection and debate aimed at overcoming some of the aforementioned difficulties, since this should make pre-service teachers securer in their professional competencies and, thus, help their pupils to obtain greater knowledge and understanding of sustainability [17]. 


\section{Conclusions}

This work has analysed some of the main difficulties of pre-service teachers in the construction of relationships between sustainability and their lifestyle during an educational intervention, focused on the problem-based learning approach and, more specifically, on the resolution of socio-ecological problems in their surroundings. This approach could promote a systemic vision to interpret the causes and consequences in the different environmental, social and economic dimensions [6,11,44], basic for EDS [12,77].

The analysis of the answers of the pre-service teachers showed that fewer difficulties were found in the identification of the pressures on SES because of our daily activities, with a greater number of accurate responses. In fact, from the stage of identification of the problems onwards, the pre-service teachers were able to discuss the influence of activities related to the generation of problems.

Nonetheless, the importance given to these systems was the component for which their responses experienced the greatest progression along the intervention. The results show the strong effect that discussing local/regional issues had, and it seems that offering opportunities to explore ecosystem services in nearby contexts could encourage students to develop a more systemic view of the interdependencies between nature and people [43]. In this sense, for future work, it should be worthwhile to plan an investigation that allows the assessment of this effect in other contexts.

The main difficulties were detected within the solutions for the conservation of the SES. The analysis of their proposals shows that, although there was a progression in their responses, they remained reluctant to assume active changes in their own habits. This conclusion is very relevant, since it confirms the importance of the existing barriers to the generation of commitments and changes towards pro-environmental behaviours, despite the progression they showed in their knowledge of the causes and consequences of different socio-ecological problems [51-53].

Although we understand that these results cannot be extrapolated to all initial teacher-training courses, they could contribute to further progress in the planning of educational programmes aimed at promoting ESD in teacher training.

Therefore, to favour an adequate establishment of the interdependences between sustainability and lifestyle, it seems that the emphasis should be on participants critically analysing their own habits as causes of certain pressures and recognising the importance of conserving the environment to their lives. Subsequently, the need to adopt changes in their behaviour may arise. Furthermore, the belief that they have the ability to reduce the threat to sustainability should be encouraged, and the action competence should be promoted among pre-service teachers.

Author Contributions: M.J.G. and P.E.-G. had the original idea, collected the data and contributed to the writing of the paper. I.B.-G. and M.J.G. wrote the paper. All authors have read and approved the final manuscript.

Funding: This research received no external funding.

Conflicts of Interest: The authors declare no conflict of interest.

\section{References}

1. UNESCO. Education for Sustainable Development. Available online: https:/en.unesco.org/themes/educationsustainable-development (accessed on 25 November 2018).

2. Álvarez-García, O.; Sureda-Negre, J.; Comas-Forgas, R. Environmental Education in Pre-Service Teacher Training: A Literature Review of Existing Evidence. J. Teach. Educ. Sustain. 2015, 17, 72-85. [CrossRef]

3. Richter-Beuschel, L.; Grass, I.; Bögeholz, S. How to Measure Procedural Knowledge for Solving Biodiversity and Climate Change Challenges. Educ. Sci. 2018, 8, 190. [CrossRef]

4. Buchanan, J. Sustainability Education and Teacher Education: Finding a Natural Habitat? Aust. J. Environ. Educ. 2012, 28, 108-124. [CrossRef]

5. Wolff, L.A.; Sjöblom, P.; Hofman-Bergholm, M.; Palmberg, I. High Performance Education Fails in Sustainability?-A Reflection on Finnish Primary Teacher Education. Educ. Sci. 2017, 7, 32. [CrossRef] 
6. Palmberg, I.; Hermans, M.; Jeronen, E.; Kärkkäinen, S.; Persson, C.; Yli-Panula, E. Nordic Student Teachers' Views on the Importance of Species and Species Identification. J. Sci. Teach. Educ. 2018, 29, 397-419. [CrossRef]

7. Kater-Wettstädt, L. How secondary-school students deal with issues of sustainable development in class. Environ. Educ. Res. 2018, 24, 1565-1580. [CrossRef]

8. Cardoso, P.; Erwin, T.L.; Borges, P.A.; New, T.R. The seven impediments in invertebrate conservation and how to overcome them. Biol. Conserv. 2011, 144, 2647-2655. [CrossRef]

9. Nisiforou, A.; Charalambides, G. Assessing Undergraduate University Students' Level of Knowledge, Attitudes and Behaviour Towards Biodiversity: A Case Study in Cyprus. Int. J. Sci. Educ. 2012, 34, 1027-1051. [CrossRef]

10. Falkenberg, T.; Babiuk, G. The status of education for sustainability in initial teacher education programmes: A Canadian case study. Int. J. Sustain. High. Educ. 2014, 15, 418-430. [CrossRef]

11. Palmberg, I.; Hofman-Bergholm, M.; Jeronen, E.; Yli-Panula, E. Systems Thinking for Understanding Sustainability? Nordic Student Teachers' Views on the Relationship between Species Identification, Biodiversity and Sustainable Development. Educ. Sci. 2017, 7, 72. [CrossRef]

12. Hofman-Bergholm, M. Could Education for Sustainable Development Benefit from a Systems Thinking Approach? Systems 2018, 6, 43. [CrossRef]

13. Alvarez-García, O.; Sureda-Negre, J.; Comas-Forgas, R. Assessing environmental competencies of primary education pre-service teachers in Spain: A comparative study between two universities. Int. J. Sustain. High. Educ. 2018, 19, 15-31. [CrossRef]

14. Hofman, M. What is an Education for Sustainable Development Supposed to Achieve-A Question of What, How and Why. J. Educ. Sustain. Dev. 2015, 9, 213-228. [CrossRef]

15. McBride, B.B.; Brewer, C.A.; Berkowitz, A.R.; Borrie, W.T.; Borrie, W. Environmental literacy, ecological literacy, ecoliteracy: What do we mean and how did we get here? Ecosphere 2013, 4, 1-20. [CrossRef]

16. Collins-Figueroa, M. Biodiversity and Education for Sustainable Development in Teacher Education Programmes of Four Jamaican Educational Institutions. J. Educ. Sustain. Dev. 2012, 6, 253-267. [CrossRef]

17. Elster, D.; Barendziak, T.; Haskamp, F.; Kastenholz, L. Raising Standards through INQUIRE in Pre-Service Teacher Education. Sci. Educ. Int. 2014, 25, 29-39.

18. Yli-Panula, E.; Jeronen, E.; Lemmetty, P.; Pauna, A. Teaching Methods in Biology Promoting Biodiversity Education. Sustainability 2018, 10, 3812. [CrossRef]

19. Novacek, M.J. Engaging the public in biodiversity issues. Proc. Natl. Acad. Sci. USA 2008, 105, 11571-11578. [CrossRef]

20. Navarro-Perez, M.; Tidball, K.G. Challenges of Biodiversity Education: A Review of Education Strategies for Biodiversity Education. Int. Electron. J. Environ. Educ. 2012, 2, 13-30.

21. Menzel, S.; Bögeholz, S. Values, beliefs and norms that foster Chilean and German pupils' commitment to protect biodiversity. Int. J. Environ. Sci. Educ. 2010, 5, 31-49.

22. Büssing, A.G.; Schleper, M.; Menzel, S. Do Pre-service Teachers Dance with Wolves? Subject-Specific Teacher Professional Development in A Recent Biodiversity Conservation Issue. Sustainability 2019, 11, 47. [CrossRef]

23. Yavetz, B.; Goldman, D.; Pe'Er, S. Environmental literacy of pre-service teachers in Israel: A comparison between students at the onset and end of their studies. Environ. Educ. Res. 2009, 15, 393-415. [CrossRef]

24. Spannring, R.; Grušovnik, T. Leaving the Meatrix? Transformative learning and denialism in the case of meat consumption. Environ. Educ. Res. 2018, 1-10. [CrossRef]

25. Álvarez-Suárez, P.; Vega-Marcote, P.; Mira, R.G. Sustainable consumption: A teaching intervention in higher education. Int. J. Sustain. High. Educ. 2013, 15, 3-15. [CrossRef]

26. Forbes, C.T.; Zint, M. Elementary Teachers' Beliefs About, Perceived Competencies for, and Reported Use of Scientific Inquiry to Promote Student Learning About and for the Environment. J. Environ. Educ. 2010, 42, 30-42. [CrossRef]

27. MacDiarmid, J.I.; Douglas, F.; Campbell, J. Eating like there's no tomorrow: Public awareness of the environmental impact of food and reluctance to eat less meat as part of a sustainable diet. Appetite 2016, 96, 487-493. [CrossRef]

28. Gallup Organization. Attitudes of Europeans towards the Issue of Biodiversity Analytical Report Wave 2-Flash Eurobarometer Brussels, Belgium: European Commission. Available online: http://ec.europa.eu/ public_opinion/flash/fl_290_en.pdf (accessed on 20 February 2019). 
29. McNeill, K.L.; Vaughn, M.H. Urban high school students' critical science agency: Conceptual understandings and environmental actions around climate change. Res. Sci. Educ. 2012, 42, 373-399. [CrossRef]

30. Dikmenli, M. Biology student teachers' conceptual frameworks regarding biodiversity. Education 2010, 130, 479-489.

31. Fiebelkorn, F.; Menzel, S. Student teachers' understanding of the terminology, distribution, and loss of biodiversity: Perspectives from a biodiversity hotspot and an industrialized country. Res. Sci. Educ. 2013, 43, 1593-1615. [CrossRef]

32. Bickel, M.; Strack, M.; Bögeholz, S. Measuring the interest of German students in agriculture: The role of knowledge, nature experience, disgust, and gender. Res. Sci. Educ. 2015, 45, 325-344. [CrossRef]

33. Meira, P.Á. Problemas ambientales globales y educación ambiental: Una aproximación desde las representaciones sociales del cambio climático. Rev. Int. Educ. 2013, 6, $29-64$.

34. Martínez, J.; Fitz, C.; Esteve, M.A.; Guaita, N.; Martínez, J. Modelización del efecto de los cambios de uso sobre los flujos de nutrientes en cuencas agrícolas costeras: El caso del Mar Menor (Sudeste de España). Rev. Ecosist. 2014, 22, 84-94. [CrossRef]

35. Spangenberg, J.H.; Lorek, S. Environmentally sustainable household consumption: From aggregate environmental pressures to priority fields of action. Ecol. Econ. 2002, 43, 127-140. [CrossRef]

36. UNEP. Marine Litter: A Global Challenge. Available online: https://wedocs.unep.org/bitstream/handle/20. 500.11822/10744/MarineLitterAglobalChallenge.pdf?sequence=1\&isAllowed=y (accessed on 2 January 2019).

37. Grace, M.; Sharp, J. Exploring the Actual and Potential Rhetoric-reality Gaps in Environmental Education and their Implications for Pre-service Teacher Training. Environ. Educ. Res. 2000, 6, 331-345. [CrossRef]

38. Varela-Losada, M.; Arias-Correa, A.; Pérez-Rodríguez, U.; Vega-Marcote, P. How Can Teachers Be Encouraged to Commit to Sustainability? Evaluation of a Teacher-Training Experience in Spain. Sustainability 2019, 11, 4309. [CrossRef]

39. Vitale, J.M.; McBride, E.; Linn, M.C. Distinguishing complex ideas about climate change: Knowledge integration vs. specific guidance. Int. J. Sci. Educ. 2016, 38, 1548-1569. [CrossRef]

40. Wijkman, A.; Rockström, J. Bankrupting Nature: Denying Our Planetary Boundaries; Routledge: New York, NY, USA, 2012; p. 224.

41. Millennium Ecosystem Assessment. Ecosystems \& Human Well-Being: Wetlands and Water Synthesis; World Resources Institute: Washington, DC, USA, 2005; p. 266.

42. Yorek, N.; Ugulu, I.; Sahin, M.; Dogan, Y. A qualitative investigation of students' understanding about ecosystem and its components. Nat. Montenegrina 2010, 9, 973-981.

43. Esteve, P.; Jaén, M.; Banos-González, I. Changes in the level of relationship between invertebrates and society of pre-service primary school teachers, after an educational intervention. J. Biol. Educ. 2019, 1-16. [CrossRef]

44. Kilinc, A.; Yeşiltaş, N.K.; Kartal, T.; Demiral, Ü.; Eroğlu, B. School Students' Conceptions about Biodiversity Loss: Definitions, Reasons, Results and Solutions. Res. Sci. Educ. 2013, 43, 2277-2307. [CrossRef]

45. Kellert, S.R. Values and Perceptions of Invertebrates. Conserv. Biol. 1993, 7, 845-855. [CrossRef]

46. Harrison, P.; Berry, P.; Simpson, G.; Haslett, J.; Blicharska, M.; Bucur, M.; Dunford, R.; Egoh, B.; García-Llorente, M.; Geamănă, N.; et al. Linkages between biodiversity attributes and ecosystem services: A systematic review. Ecosyst. Serv. 2014, 9, 191-203. [CrossRef]

47. Prip, C. The Convention on Biological Diversity as a legal framework for safeguarding ecosystem services. Ecosyst. Serv. 2018, 29, 199-204. [CrossRef]

48. Schönfelder, M.L.; Bogner, F.X. How to sustainably increase students' willingness to protect pollinators. Environ. Educ. Res. 2018, 24, 461-473. [CrossRef]

49. Lindemann-Matthies, P.; Constantinou, C.; Junge, X.; Köhler, K.; Mayer, J.; Nagel, U.; Raper, G.; Schüle, D.; Kadji-Beltran, C. The integration of biodiversity education in the initial education of primary school teachers: Four comparative case studies from Europe. Environ. Educ. Res. 2009, 15, 17-37. [CrossRef]

50. Sanmartí, N.; Etxaburu, B.B.; Angós, T.N. Por qué el alumnado tiene dificultad para utilizar sus conocimientos científicos escolares en situaciones cotidianas? Alambique 2011, 67, 62-69.

51. Kollmuss, A.; Agyeman, J. Mind the Gap: Why do people act environmentally and what are the barriers to pro-environmental behavior? Environ. Educ. Res. 2002, 8, 239-260. [CrossRef]

52. Stoll-Kleemann, S.; Schmidt, U.J. Reducing meat consumption in developed and transition countries to counter climate change and biodiversity loss: A review of influence factors. Reg. Environ. Chang. 2017, 17, 1261-1277. [CrossRef] 
53. Zelenika, I.; Moreau, T.; Lane, O.; Zhao, J. Sustainability education in a botanical garden promotes environmental knowledge, attitudes and willingness to act. Environ. Educ. Res. 2018, 24, 1581-1596. [CrossRef]

54. Zsóka, Á.; Szerényi, Z.M.; Széchy, A.; Kocsis, T. Greening due to environmental education? Environmental knowledge, attitudes, consumer behavior and everyday pro-environmental activities of Hungarian high school and university students. J. Clean. Prod. 2013, 48, 126-138. [CrossRef]

55. Otto, S.; Pensini, P. Nature-based environmental education of children: Environmental knowledge and connectedness to nature, together, are related to ecological behaviour. Glob. Environ. Chang. 2017, 47, 88-94. [CrossRef]

56. Hedefalk, M.; Almqvist, J.; Östman, L. Education for sustainable development in early childhood education: A review of the research literature. Environ. Educ. Res. 2015, 21, 975-990. [CrossRef]

57. Olsson, D.; Gericke, N.; Chang Rundgren, S.N. The effect of implementation of education for sustainable development in Swedish compulsory schools-assessing pupils' sustainability consciousness. Environ. Educ. Res. 2016, 22, 176-202. [CrossRef]

58. Jaén, M.; Barbudo, P. Evolución de las percepciones medioambientales de los alumnos de educación secundaria en un curso académico. Rev. Eureka Enseñ. Divul. Cien. 2010, 7, 247-259. [CrossRef]

59. De Bakker, E.; Dagevos, H. Reducing meat consumption in today's consumer society: Questioning the citizen-consumer gap. J. Agric. Environ. Ethic. 2012, 25, 877-894. [CrossRef]

60. Vega-Marcote, P.; Varela-Losada, M.; Álvarez-Suárez, P. Evaluation of an Educational Model Based on the Development of Sustainable Competencies in Basic Teacher Training in Spain. Sustainability 2015, 7, 2603-2622. [CrossRef]

61. Tuncer, G.; Boone, J.W.; Tuzun, O.Y.; Oztekin, C. An evaluation of the environmental literacy of preservice teachers in Turkey through Rasch analysis. Environ. Educ. Res. 2014, 20, 202-227. [CrossRef]

62. Palmer, J.A.; Suggate, J. Influences and Experiences Affecting the Pro-environmental Behaviour of Educators. Environ. Educ. Res. 1996, 2, 109-121. [CrossRef]

63. Cotton, D.R.E. Implementing curriculum guidance on environmental education: The importance of teachers' beliefs. J. Curric. Stud. 2006, 38, 67-83. [CrossRef]

64. Evans, N.; Whitehouse, H.; Hickey, R. Pre-service Teachers' Conceptions of Education for Sustainability. Aust. J. Teach. Educ. 2012, 37. [CrossRef]

65. Kuvac, M.; Koc, I. The effect of problem-based learning on the environmental attitudes of preservice science teachers. Educat. Stud. 2019, 45, 72-94. [CrossRef]

66. Vare, P.; Scott, W.A.H. Two Sides and an Edge; DEA: London, UK, 2008.

67. Esteve-Guirao, P. Los Futuros Maestros Ante Problemáticas Sobre la Conservación de la Biodiversidad y su Utilización en las Aulas de Educación Primaria [Future Teachers Facing Problems of Biodiversity Conservation and Their Teaching in Primary Education]. Ph.D. Thesis, University of Murcia, Murcia, Spain, 2016.

68. Vasconcelos, C. Teaching environmental education through PBL: Evaluation of a teaching intervention program. Res. Sci. Educ. 2012, 42, 219-232. [CrossRef]

69. Bell, R.L.; Smetana, L.; Binns, I. Simplifying inquiry instruction: Assessing the inquiry level of classroom activities. Sci. Teach. 2005, 72, 30-33.

70. Pyle, E.J. A model of inquiry for teaching earth science. Elect. J. Sci. Educ. 2008, 12, 3-21.

71. Miles, M.B.; Huberman, M.A. Qualitative Data Analysis; Sage: Thousand Oaks, CA, USA, 1994.

72. Bastian, B.; Loughnan, S. Resolving the meat-paradox: A motivational account of morally troublesome behavior and its maintenance. Pers. Soc. Psychol. Rev. 2017, 21, 278-299. [CrossRef] [PubMed]

73. Jaén, M.; Palop, E. Qué piensan y cómo dicen que actúan los alumnos y profesores de un centro de educación secundaria sobre la gestión del agua, la energía y los residuos? [What do students and teachers in a secondary school think about water, energy and waste management?]. Enseñanza Cienc. 2011, 29, 61-74.

74. Martínez, M.; Jaén, M. Ante un problema medioambiental real sobre el agua: Qué piensan y qué están dispuestos a hacer los alumnos de educación ambiental? In Educación Científica: Tecnologías de la Información y la Comunicación y Sostenibilidad; Prensas Universitarias de Zaragoza: Zaragoza, Spain, 2006; p. 59.

75. McKeown-Ice, R. Environmental Education in the United States: A Survey of Preservice Teacher Education Programs. J. Environ. Educ. 2000, 32, 4-11. [CrossRef] 
76. Summers, M.; Krüger, C.; Childs, A.; Mant, J. Primary School Teachers' Understanding of Environmental Issues: An interview study. Environ. Educ. Res. 2000, 6, 293-312. [CrossRef]

77. Álvarez-García, O.; García-Escudero, L.Á.; Salvà-Mut, F.; Calvo-Sastre, A. Variables Influencing Pre-Service Teacher Training in Education for Sustainable Development: A Case Study of Two Spanish Universities. Sustainability 2019, 11, 4412.

(C) 2019 by the authors. Licensee MDPI, Basel, Switzerland. This article is an open access article distributed under the terms and conditions of the Creative Commons Attribution (CC BY) license (http://creativecommons.org/licenses/by/4.0/). 